\title{
Experimental investigation on lubricity of 2,5-dimethylfuran blends
}

\begin{abstract}
Spark ignition engines fuelled with alternative fuels are the topic of many studies. As alternatives for gasoline, ethanol and recently 2,5-dimethylfuran (DMF) have been investigated for their different properties. Lubricity analysis of fuels in fuel systems is vital because of the lubricating role of fuel. Lubricity of gasoline and its alternatives became important since introduction of direct-injection gasoline fuel pump with high injection pressure becoming closer to diesel pumps. Therefore, this work examines the lubricity properties of gasoline and its blends with alternative fuels using a HFRR lubricity test rig. Results showed that DMF as an additive to gasoline improved the lubricity of blend; this effect was increasing with the percentage of DMF. These results can be compared with DMF-ethanol blends which displayed the same pattern but with lower enhancing role of DMF. The DMF fuel was kept in storage for seven months and then the same experiments were repeated (DMF Ageing). Smaller wear scar and better lubricity effects were achieved by using the aged DMF. These results highlight the potential of DMF to become an additive for gasoline and its alternatives.
\end{abstract}

Key words: lubricity, 2,5-dimethylfuran, HFRR, wear scar, gasoline, ethanol

\section{Badania eksperymentalne właściwości smarnych paliw zawierających 2,5-dwumetylofuran (DMF)}

\begin{abstract}
Silniki o zapłonie iskrowym (ZI) zasilane paliwami alternatywnymi sa tematem wielu programów badawczych. Badane sa różne właściwości paliw alternatywnych dla benzyny, etanolu, a ostatnio również 2,5-dwumetylofuranu (DMF). Z uwagi na role paliwa jako czynnika smarujacego nieodzowne jest prowadzenie badań smarności paliw alternatywnych. Wprowadzenie wysokociśnieniowych pomp paliwa i systemów zasilania z wtryskiem bezpośrednim do silników o zapłonie iskrowym wymaga dobrej smarności stosowanych paliw. W artykule zaprezentowano wyniki badań smarności przeprowadzonych z użyciem aparatu o ruchu posuwisto-zwrotnym wysokiej częstotliwości (HFRR) dla mieszanek benzyny i paliw alternatywnych. Wyniki wykazuja, że dodatek DMF poprawia właściwości smarne paliw wraz ze wzrostem zawartości DMF w mieszance. Podobna tendencję zaobserwowano dla mieszanek DMF i etanolu, $w$ których jednak pozytywny wpływ DMF jest mniej widoczny. Badania powtórzono przy użyciu DMF przechowywanego przez 7 miesięcy. Zmierzone średnice śladu zużycia wskazują na lepsze właściwości smarne tak sezonowanego DMF. Wyniki przeprowadzonych badań potwierdzaja duży potencjat 2,5-dwumetylofuranu jako dodatku poprawiajacego smarność benzyn i etanolu.
\end{abstract}

Słowa kluczowe: smarność, 2,5-dwumetylofuran, HFRR, benzyna, etanol, średnica śladu zużycia

\section{Introduction}

Damage caused by changes in global temperature made several countries aware of the dangers threatening their people and environment. As a part solution to this problem different countries (especially in the European Union) introduced strict regulations for greenhouse gas emissions from internal combustion engines. Fuels used for transportation sector must have specific physical properties allowing efficient combustion, storage and distribution. These properties are all available with non-renewable petroleum based fuels. Ethanol as the only mass produced renewable fuel for SI engines fulfils many of these properties, but still with many limitations $[1,2]$. In parallel, fuels must provide adequate lubrication of the moving parts in the fuel supply system, thus research on the effect of specification of fuel compositions on lubricity is of paramount importance $[3,4]$.

Among the fuels available for gasoline alteration or additive, ethanol is an attractive candidate with huge sources of production and also simple fabrication process [2]. Another potential alternative for gasoline is 2,5-dimethylfuran (DMF)

\section{Wprowadzenie}

Szkody wywołane przez zmiany klimatu spowodowały w wielu krajach wzrost świadomości ludzi zagrożeń dla środowiska. Częściowym rozwiązaniem problemu jest wprowadzenie limitów emisji gazów cieplarnianych przez silniki pojazdów samochodowych (szczególnie w krajach UE). Paliwa używane do napędu pojazdów samochodowych muszą charakteryzować się odpowiednimi właściwościami zapewniającymi dobry przebieg procesu spalania, łatwość ich przechowywania i dystrybucji. Właściwościami takimi charakteryzują się paliwa otrzymywane w procesie rafinacji ropy naftowej. Etanol, jako jedyne biopaliwo produkowane na skale masową, spełnia większość wymienionych wymagań, chociaż występują ograniczenia jego stosowania [1,2]. Paliwa muszą jednocześnie wykazywać dobre właściwości smarne, zapewniając tym samym odpowiednią współpracę ruchomych elementów systemu zasilania; z tego względu badania nad wpływem składu paliwa na smarność mają duże znaczenie $[3,4]$.

Wśród paliw alternatywnych i dodatków do benzyn, etanol może być rozpatrywany jako atrakcyjny ze względu 
[5]. There are prospective improvements in large scale production of DMF as Leshkov et al. proposed a catalytic strategy for the production of this fuel [6]. Also as Daniel, Leshkov et al. and others mentioned in their papers, DMF has many physico-chemical properties competitive to ethanol and also gasoline; these properties include boiling point, energy density and very good anti-knock qualities [6,7].

There are many investigations published on diesel and biodiesel fuel lubricity characteristics, but there is lack of data on lubricity of gasoline and gasoline type bio-fuels. Most gasoline fuel injection systems inject fuel into the inlet port upstream of the inlet valves; consequently the operation is at much lower pressure compared to diesel pumps $[8,9]$. This reduction in operation pressure results in lower lubricity requirements for gasoline compared with diesel [10]. It was discovered that gasoline which has higher sulphur content, has good lubricity. It is believed that this good lubricity is a result of polar-type compounds which absorb themselves into the alloy and form a protective film coating [11].

Ping et al. [10] was the first groups researching the lubricity of gasoline. They modified the High Frequency Reciprocating Rig (HFRR) which is mainly used as the instrument for measuring the lubricity of diesel fuel for testing the gasoline. They reported that the gasoline without additives gave higher wear than highly refined Class I diesel fuels. Also they reported that adding detergent additives to gasoline decreases the wear. Lapuerta et al. [12] reported that adding ethanol to biodiesel blends resulted in loss of lubricity at high concentrations of ethanol in blend. Agudelo et al. [13] reported that adding different percentages of ethanol to gasoline (E20-E85) did not impact significantly the blend lubricity, but that addition of hydrated ethanol slightly improved blend lubricity in comparison with adding anhydrous ethanol.

In this paper the lubricity of DMF, gasoline and ethanol will be compared.

\section{Methodology}

The experiments were performed using the High Frequency Reciprocating Rig (HFRR). The conventional HFRR test rig is used for measuring diesel fuel lubricity, in this rig an open fuel bath is used, but due to high volatility of gasoline this rig was modified by using a gasoline conversion kit preventing excessive evaporation. The HFRR makes possible

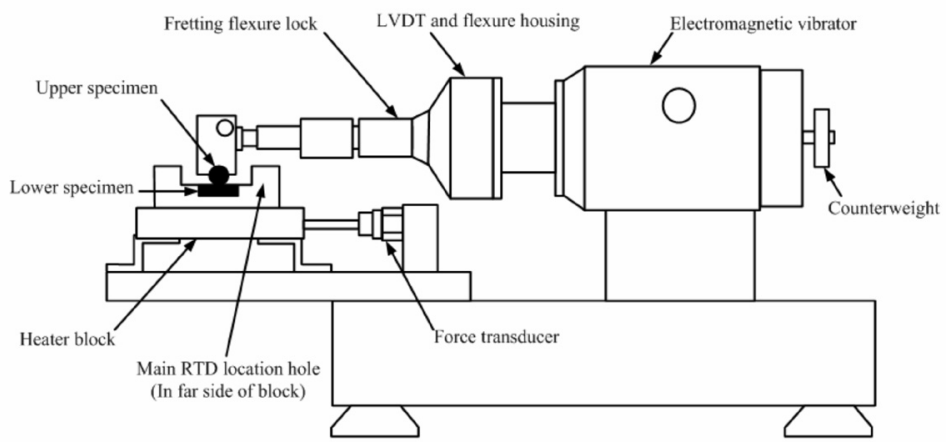

Fig. 1. Schematic diagram of HFRR

Rys. 1. Schemat aparatu HFRR na szeroką dostępność surowca - biomasy, jak również prosty proces jego otrzymywania [2]. Inną substancją, która może stanowić alternatywę dla benzyn jest 2,5-dwumetylofuran DMF [5]. Proponowany proces produkcji DMF ulega ciągłym modyfikacjom; Leshkov i in. proponują otrzymywanie paliwa na drodze katalitycznej. Zarówno Daniel, jak i Leshkov wskazują na istotne podobieństwo właściwości fizycznych i chemicznych DMF do właściwości benzyn i etanolu, takich jak: temperatura wrzenia, wartość opałowa i właściwości przeciwstukowe $[6,7]$.

Opublikowano liczne wyniki badań nad smarnością olejów napędowych i biodiesla, brakuje natomiast danych dotyczących smarności benzyn i ich zamienników. Większość silników o zapłonie iskrowym wyposażona jest w system wielopunktowego wtrysku paliwa z wtryskiwaczem umieszczonym przed zaworem dolotowym. Cechą charakterystyczną tych systemów jest ciśnienie wtrysku znacznie niższe od ciśnienia systemów stosowanych w silnikach o zapłonie samoczynnym $[8,9]$. Wymagania dotyczące właściwości smarnych są mniejsze ze względu na niższe ciśnienie pracy układu [10]. Benzyny o większej zawartości siarki mają lepsze właściwości smarne. Występujące cząstki polarne przylegają do podłoża i tworzą cienką warstwę ochronną współpracujących powierzchni [11].

Pierwsze wyniki badań nad smarnością benzyn zostały opublikowane przez Pinga i in. [10]. Aparat o ruchu posuwisto-zwrotnym wysokiej częstotliwości (HFRR), używany do badań olejów napędowych, został zmodyfikowany i przystosowany do badania benzyn. Otrzymana średnica śladu zużycia była dla benzyny bez dodatków większa niż dla wysokorafinowanego oleju napędowego (klasy 1). Zastosowanie dodatków myjących poprawiło właściwości smarne. Negatywny wpływ dużej zawartości etanolu w mieszaninie $\mathrm{z}$ biodieslem na smarność został opisany przez Lapuerta i in. [12]. Badania prowadzone przez Agudelo i in. [13] wskazują na niewielki wpływ dodatku etanolu do benzyny na smarność mieszaniny E20-E85. Wprowadzenie etanolu uwodnionego do mieszanki nieznacznie poprawiło smarność mieszaniny $\mathrm{w}$ porównaniu ze smarnością etanolu odwodnionego.

W niniejszej publikacji porównano smarność benzyn, etanolu i DMF.

\section{Metoda badań}

Badania przeprowadzono przy użyciu aparatu o ruchu posuwisto-zwrotnym wysokiej częstotliwości. Aparat jest przeznaczony do badania smarności olejów napędowych i wyposażony w otwarty zbiornik badanego paliwa. Stanowisko HFRR przystosowano do badań paliw o zwiększonej lotności przez zainstalowanie zestawu adaptacyjnego zawierającego między innymi zamknięty zbiornik paliwa ograniczający parowanie próbki. Aparat HFRR umożliwia szacowanie smarności olejów i paliw z dużą dokładnością i powtarzalnością. Schemat stanowiska przedstawiono na rys. 1. Warunki przeprowadzenia testu podano $\mathrm{w}$ tabeli 1 .

Paliwa użyte do testów charakteryzują się różną czystością i właściwościami. 2,5-dwumetylofuran 
Table 1. HFRR test conditions

Tabela 1. Warunki testów HFRR

\begin{tabular}{|l|c|}
\hline Parameter/parametr & Value/wartość \\
\hline Fluid volume/objętość próbki płynu, $\mathrm{ml}$ & $2 \pm 0.2$ \\
\hline Stroke length/dtugość skoku, $\mathrm{mm}$ & $1 \pm 0.02$ \\
\hline Frequency/częstotliowść, $\mathrm{Hz}$ & $50 \pm 1$ \\
\hline Fluid temperature/temperatura płynu, ${ }^{\circ} \mathrm{C}$ & $25 \pm 1$ \\
\hline Test load mass/obciążenie, g & 200 \\
\hline Test duration/czas trwania testu, min & $75 \pm 0.1$ \\
\hline
\end{tabular}

dostarczyła firma Shijiazhuang Lida Chemical Co., Ltd, Chiny, benzynę oraz etanol - firma Shell Global Solutions, UK. Właściwości badanych paliw przedstawiono w tabeli 2.

\section{Wyniki i dyskusja}

Smarność paliw oceniono przez pomiar pod mikroskopem średnicy śladu zużycia, uzyskanej po 75 minutach testu. Największą średnicę śladu zużycia zmierzono dla benzyny - $714 \mu \mathrm{m}$, a najmniejszą dla DMF - 238,5 $\mu \mathrm{m}$. DMF charakteryzuje się najlepszymi właściwościami smarnymi w porównaniu z właściwościami benzyny lub etanolu. Zmiany

Table 2. Test fuel properties

Tabela 2. Wtaściwości badanych paliw

\begin{tabular}{|c|c|c|c|}
\hline Properties/wtaściwości & DMF & Ethanol/etanol & Gasoline/benzyna \\
\hline Summary chemical formula/sumaryczny wzór chemiczny & $\mathrm{C}_{6} \mathrm{H}_{8} \mathrm{O}$ & $\mathrm{C}_{2} \mathrm{H}_{6} \mathrm{O}$ & $\mathrm{C}_{2}-\mathrm{C}_{14}$ \\
\hline $\begin{array}{l}\text { Density at } / \text { gęstość przy } 20{ }^{\circ} \mathrm{C} \\
\left(\mathrm{kg} / \mathrm{m}^{3}\right) / *\end{array}$ & $889.7^{*}$ & $790.9^{*}$ & 744.6 \\
\hline Gravimetric oxygen content/masowa zawartość tlenu (\%) & 16.67 & 34.78 & 0 \\
\hline $\mathrm{H} / \mathrm{C}$ ratio/stosunek $H / C$ & 1.333 & 3 & 1.795 \\
\hline $\mathrm{O} / \mathrm{C}$ ratio/stosunek $\mathrm{O} / \mathrm{C}$ & 0.167 & 0.5 & 0 \\
\hline $\begin{array}{l}\text { Stoichiometric air/fuel ratio (gravimetric)/stechiometryczny (masowy) stosunek } \\
\text { powietrze/paliwo }(\mathrm{kg} / \mathrm{kg})\end{array}$ & 10.72 & 8.95 & 14.46 \\
\hline $\mathrm{LHV} /$ mniejsze ciepto spalania $(\mathrm{MJ} / \mathrm{kg})$ & $33.7^{*}$ & $26.9^{*}$ & 42.9 \\
\hline Initial boiling point/poczatkowa temperatura wrzenia $\left({ }^{\circ} \mathrm{C}\right)$ & 92 & 78.4 & 32.8 \\
\hline Research Octane Number/liczba oktanowa metoda badawcza (RON) & $\mathrm{n} / \mathrm{a}$ & 106 & 96.8 \\
\hline Heat of vaporization/entalpia parowania $(\mathrm{kJ} / \mathrm{kg})$ & 332 & 840 & 373 \\
\hline
\end{tabular}

* Measured at the University of Birmingham /zmierzono na Uniwersytecie Birmingham

performance assessment of lubricants with high accuracy and repeatability. The schematic diagram of the rig used for these experiments is shown in Figure 1. Test conditions are presented in Table 1.

Fuels used for these experiments have different purity and properties. 2,5-dimethylfuran was supplied by Shijiazhuang Lida Chemical Co., Ltd, China. Gasoline and ethanol were supplied by Shell Global Solutions UK. The properties of all fuels are listed in Table 2.

\section{Results and discussion}

In the HFRR lubricity test, for pure DMF, ethanol and gasoline results have been obtained after 75 minutes of test

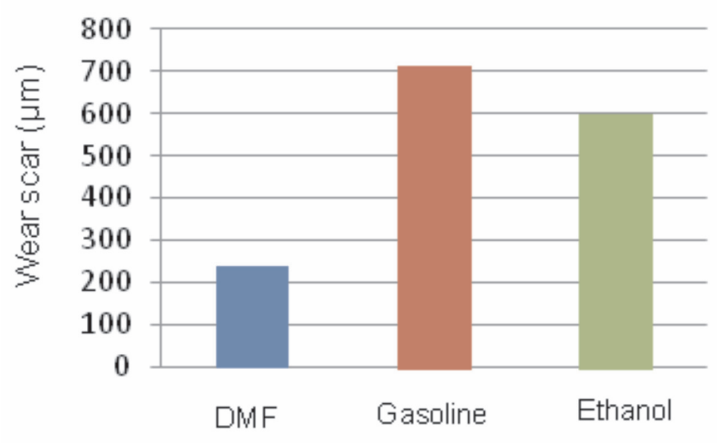

Fuel

Fig. 2. Comparison of pure fuels wear scar sizes Rys. 2. Porównanie średnicy śladu zużycia
Table 3. Pure fuels wear scar sizes

Tabela 3. Średnica śladu zużycia badanych paliw

\begin{tabular}{|c|c|}
\hline Pure fuels/paliwo & $\begin{array}{c}\text { Wear scar/średnica śladu zużycia } \\
(\mu \mathrm{m})\end{array}$ \\
\hline DMF & 238.5 \\
\hline Ethanol/etanol & 596 \\
\hline Gasoline/benzyna & 714 \\
\hline
\end{tabular}

współczynnika tarcia i udziału powierzchniowego filmu dla trzech badanych paliw przedstawiono na rys. 3 i 4 dla warunków testu: temperatura $25{ }^{\circ} \mathrm{C}$ i wilgotność względna $35-45 \%$.

Spośród badanych paliw największe zmiany i wahania współczynnika tarcia zanotowano dla benzyny, stąd też największa zmierzona średnica śladu zużycia.

Współczynnik tarcia dla DMF jest względnie niezmienny podczas przeprowadzania testu, $\mathrm{w}$ przeciwieństwie do współczynników uzyskanych dla benzyny i etanolu, które wykazują tendencje do wzrostu w miarę upływu czasu trwania testu.

Analiza wykresów przedstawionych na rys. 3 pozwala stwierdzić, że współczynnik tarcia, który dla DMF wynosi 0,271 jest niższy od współczynnika zmierzonego dla benzyny $(0,466)$ o prawie $42 \%$ oraz jest ponad $20 \%$ niższy od współczynnika zmierzonego dla etanolu $(0,355)$. Potwierdza to dobre właściwości smarne DMF. Udział powierzchniowy filmu smarnego, przedstawiony na rys. 4 , wynosi $68 \%$ i jest 


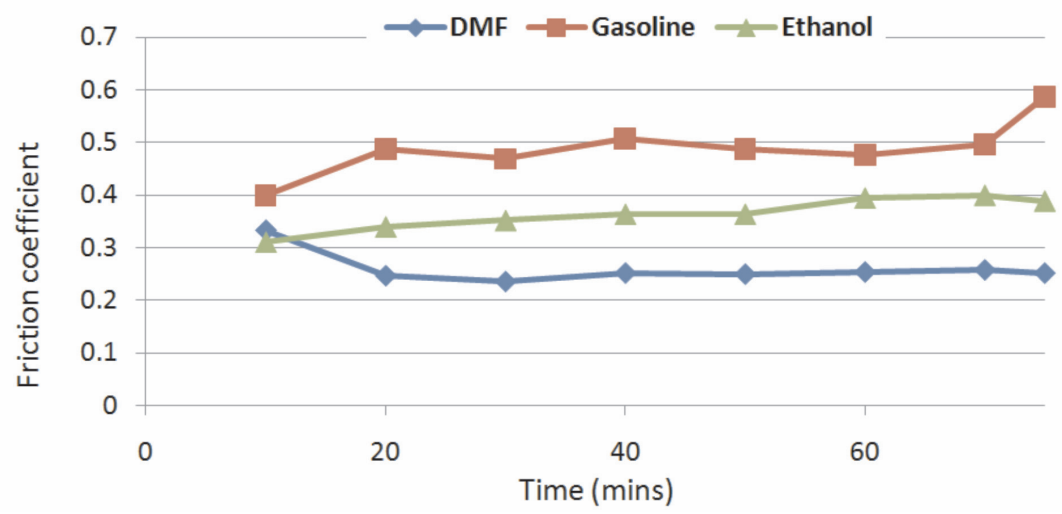

Fig. 3. Friction coefficient comparison of pure fuels during experiment (75 minutes)

Rys. 3. Porównanie wspólczynnika tarcia badanych paliw podczas testu (75 minut) znacząco wyższy niż wartości zmierzone dla benzyny (53\%) i etanolu (46\%). Większy udział powierzchniowy filmu dla DMF może skutkować zmniejszeniem średnicy śladu zużycia. Największy zmierzony udział powierzchniowy filmu dla DMF wynosił $83 \%$.

\section{Mieszanki DMF z benzyną i etanolem}

$\mathrm{Na}$ rysunkach 5 i 6 przedstawiono wpływ zawartości DMF w mieszance $\mathrm{z}$ benzyną na współczynnik tarcia i udział filmu. Mieszanki o większym udziale DMF charakteryzują się znacznie niższym współczynnikiem tarcia. Dla

and by measuring wear scar under the microscope; the results show that the largest wear scar is for gasoline $-714 \mu \mathrm{m}$ and the lowest one is for DMF - 238.5 $\mu \mathrm{m}$. Therefore, DMF has the best lubricity in comparison with ethanol and gasoline. Figures 3 and 4 illustrate how friction coefficient and lubrication film of DMF, ethanol and gasoline change with time at $35-45 \%$ relative humidity and $25{ }^{\circ} \mathrm{C}$.

Among tested fuels, gasoline displays biggest changes and large fluctuations in friction

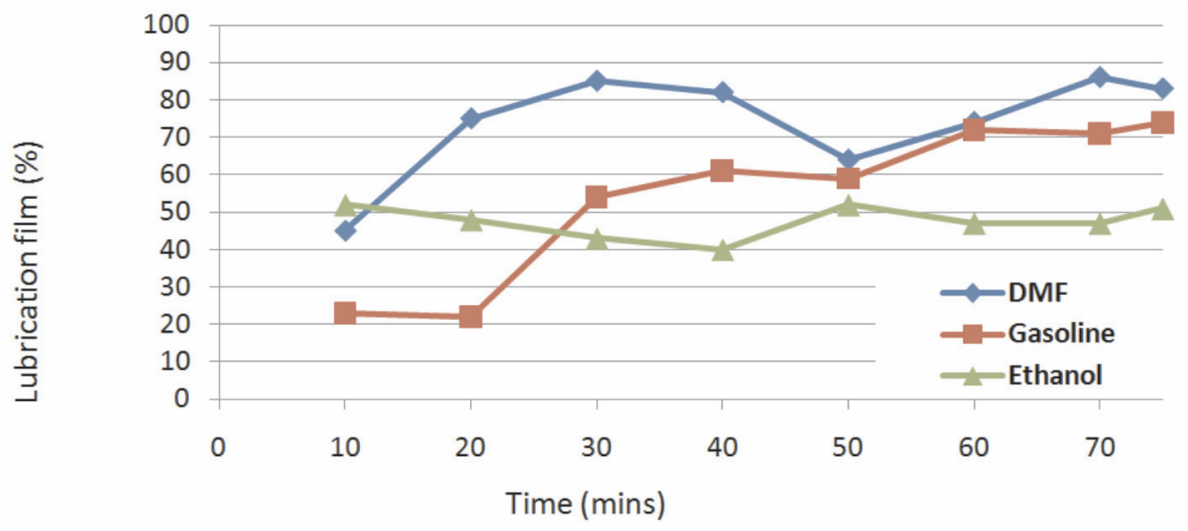

Fig. 4. Lubrication film comparison of pure fuels during experiment (75 minutes) Rys. 4. Porównanie udziału filmu badanych paliw podczas testu (75 minut) coefficient during the test, and this is why it has the largest wear scar.

The friction coefficients of DMF are relatively stable and constant during the experiment in comparison with gasoline and ethanol which display increasing trends.

Figure 3 demonstrates that the average friction coefficient

mieszanek o zawartości DMF w granicach 0-70\% zaobserwowano zmienny udział filmu, najprawdopodobniej spowodowany błędami pomiarowymi lub wahaniami warunków pomiaru, takimi jak temperatura paliwa lub wilgotność powietrza. Badania wykazały obniżenie współczynnika tarcia i zużycia powierzchni nawet dla niewielkiej zawartości DMF of DMF is 0.271 which is almost $42 \%$ lower than that of gasoline $(0.466)$ and over $20 \%$ lower than that of ethanol (0.355). That is why DMF has the best lubricity among three fuels. Also, the average percentage of lubrication film coverage of the three fuels has been illustrated in Figure 4 where DMF average lubrication film coverage is $68 \%$ while this value is $53 \%$ and $46 \%$ for gasoline and ethanol respectively. High film coverage of DMF can result in smaller wear scar. Highest value of film coverage for DMF is $83 \%$ during experiment.

\section{DMF blends with gasoline and ethanol}

Figures 5 and 6 demonstrate the effect of DMF concentration in blends with gasoline on the values of friction coefficient and lubrica-

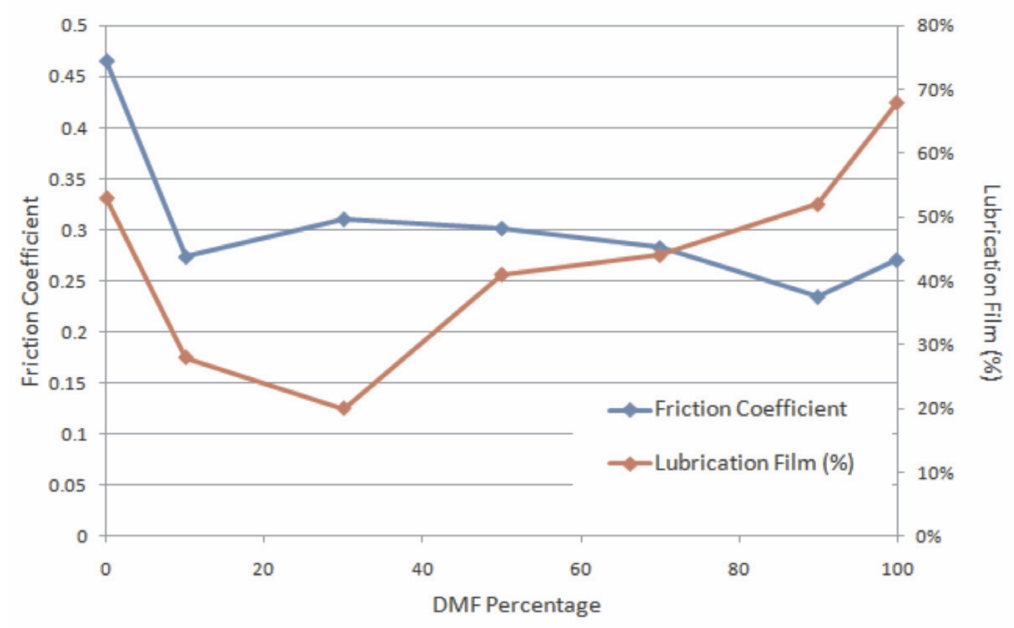

Fig. 5. Friction coefficient and lubrication film coverage effect of DMF and gasoline blends Rys. 5. Wspótczynnik tarcia i udział powierzchniowy filmu dla mieszanin DMF i benzyny 


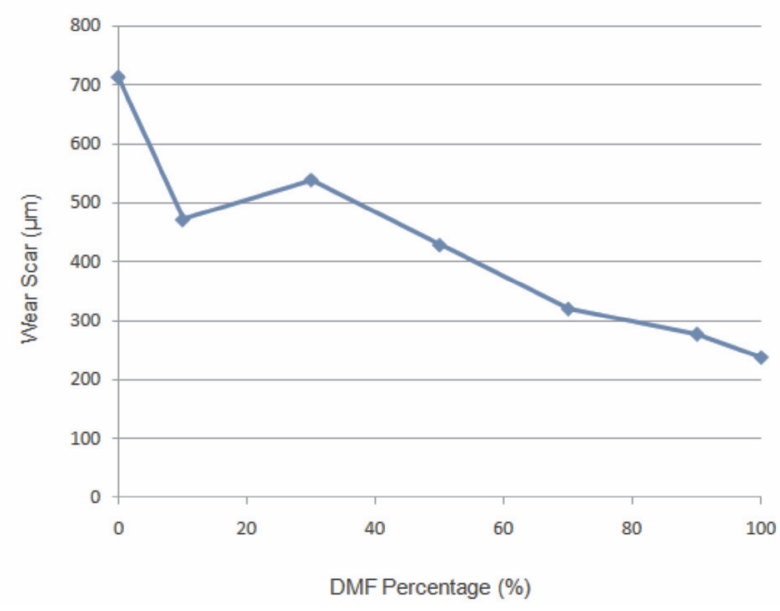

Fig. 6. Wear scars of DMF and gasoline blends

Rys. 6. Średnica śladu zużycia dla mieszanin DMF i benzyny

tion film coverage. It seems obvious that friction coefficient decreases gradually for larger percentages of DMF and lubrication film coverage has increasing trend with larger concentration of DMF in the blends. For $0 \%$ to $70 \% \mathrm{DMF}$ blends, some irregularities can be seen in the lubrication films results due to experimental errors such as controlling temperature of fuel or relative humidity; these kinds of errors can have a direct effect on the lubrication film coverage. It can be concluded that there is a decreasing trend in wear and friction coefficient at low concentration of DMF in blends with gasoline. By addition of $10 \%$ of DMF the wear scar size is reduced by almost $34 \%$ to $472 \mu \mathrm{m}$ from $714 \mu \mathrm{m}$ at $0 \% \mathrm{DMF}$.

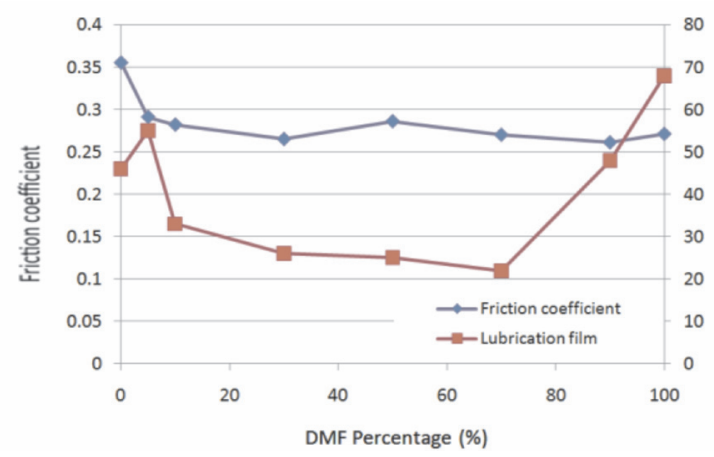

Fig. 7. Friction coefficient and lubrication film effect of DMF and ethanol blends

Rys. 7. Wplyw stężenia DMF na współczynnik tarcia i udziat powierzchniowy filmu dla mieszanin etanolu i DMF

w mieszance. Dodatek 10\% DMF skutkuje zmniejszeniem średnicy śladu zużycia o prawie $34 \%$ z $714 \mu \mathrm{m}$ do $472 \mu \mathrm{m}$. Zwiększanie zawartości DMF w mieszance powoduje dalsze zmniejszanie średnicy śladu zużycia. Dla zawartości 90\% średnica śladu zużycia spadła do $278 \mu \mathrm{m}$.

Na rysunku 7 przedstawiono wpływ zawartości DMF w mieszance $\mathrm{z}$ etanolem na współczynnik tarcia i udział powierzchniowy filmu. Zaobserwowano zróżnicowany wpływ zwiększania zawartości DMF w mieszance na współczynnik tarcia i udział powierzchniowy filmu. Współczynnik tarcia początkowo obniżył się, a następnie nie ulegał zmianie w miarę zwiększania zawartości DMF. Średnica śladu zużycia i współczynnik tarcia są niższe
Larger concentrations of DMF in blends can further decrease the wear scar size. At $90 \%$ DMF, the wear scar size reduced to $278 \mu \mathrm{m}$.

Figure 7 indicates friction coefficient and lubrication film coverage for dif-

\begin{tabular}{|c|c|c|c|}
\hline $\begin{array}{c}\text { Fuel blend/ } \\
\text { mieszanina }\end{array}$ & $\begin{array}{c}\text { Average wear scar/średnia } \\
\text { średnica śladu zużycia }(\mu \mathrm{m})\end{array}$ & $\begin{array}{c}\text { Average friction coefficient// } \\
\text { średni wspótczynnik tarcia }\end{array}$ & $\begin{array}{c}\text { Average lubrication film coverage/ } \\
\text { średni udziat powierzchniowy filmu }\end{array}$ \\
\hline 100GAS & 714 & 0.466 & $53 \%$ \\
\hline 10DMF90GAS & 472 & 0.274 & $28 \%$ \\
\hline 30DMF70GAS & 539.5 & 0.311 & $20 \%$ \\
\hline 50DMF50GAS & 429 & 0.302 & $41 \%$ \\
\hline 70DMF30GAS & 322 & 0.283 & $44 \%$ \\
\hline 90DMF10GAS & 278 & 0.235 & $41 \%$ \\
\hline 100DMF & 238.5 & 0.271 & $68 \%$ \\
\hline
\end{tabular}

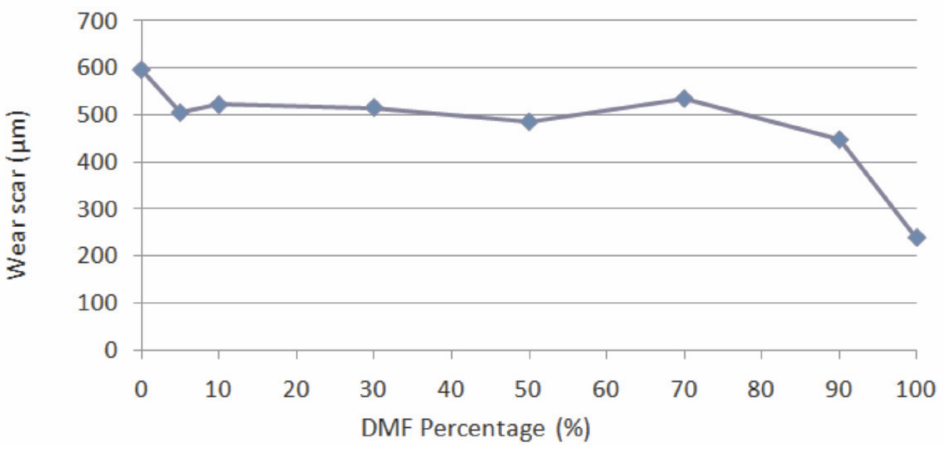

Fig. 8. Wear scars of DMF and ethanol blends

Rys. 8. Wplyw stężenia DMF na średnice śladu zużycia mieszanin etanolu i DMF nawet dla niewielkiej zawartości DMF w mieszance $\mathrm{z}$ etanolem.

Udział powierzchniowy filmu spadł o $28 \%$ przy zawartości 10\% DMF w mieszance. Dalsze zwiększanie zawartości nie zaowocowało znaczącą zmianą udziału filmu. Średnica śladu zużycia dla mieszanki o 10\% zawartości DMF zmniejszyła się o $12 \%$ od $596 \mu \mathrm{m}$ do $521,5 \mu \mathrm{m}$ (w porównaniu do zmniejszenia o $38 \%$ dla mieszanki z benzyną) i pozostała przy tej wartości aż do $70 \%$ DMF. Dla 90\% zawartości DMF średnica śladu zużycia zmniejszyła się do $447 \mu \mathrm{m}$. Na rysunku 8 przedstawiono porównanie wpływu zawartości 
Table 5. 2,5-dimethylfuran and ethanol blend test results

Tabela 5. Wyniki badań dla mieszanin etanolu $i \mathrm{DMF}$

\begin{tabular}{|c|c|c|c|}
\hline $\begin{array}{c}\text { Fuel blend/ } \\
\text { mieszanina }\end{array}$ & $\begin{array}{c}\text { Average wear scar/średnica } \\
\text { śladu zużycia }(\mu \mathrm{m})\end{array}$ & $\begin{array}{c}\text { Average friction coefficient/ } \\
\text { średni wspótczynnik tarcia }\end{array}$ & $\begin{array}{c}\text { Average lubrication film cover- } \\
\text { age/średni } u d z i a t ~ f i l m u\end{array}$ \\
\hline 100ETH & 596 & 0.355 & $46 \%$ \\
\hline 10DMF90ETH & 521.5 & 0.282 & $33 \%$ \\
\hline 30DMF70ETH & 515.5 & 0.265 & $26 \%$ \\
\hline 50DMF50ETH & 485 & 0.286 & $25 \%$ \\
\hline 70DMF30ETH & 534.5 & 0.27 & $22 \%$ \\
\hline 90DMF10ETH & 447 & 0.261 & $48 \%$ \\
\hline 100DMF & 238.5 & 0.271 & $68 \%$ \\
\hline
\end{tabular}

ferent percentages of DMF and ethanol blends. It was realized that by increasing the percentage of DMF, the friction coefficient and lubrication film coverage varied differently. The friction coefficient dropped initially and then remained relatively constant for increasing concentrations of DMF in the blend. There is a reduction in both the wear scar and friction coefficient for lower DMF concentration in blends with ethanol.

The lubrication film coverage was decreased by $28 \%$ upon addition of $10 \% \mathrm{DMF}$ after which it fluctuates upon further addition. In DMF and ethanol blends, $10 \% \mathrm{DMF}$ reduced the wear by $12 \%$ from $596 \mu \mathrm{m}$ to $521.5 \mu \mathrm{m}$ compared to the $38 \%$ reduction in gasoline and it stayued at around $525 \mu \mathrm{m}$ until 70\% DMF in the blend. The wear scar was decreased to $447 \mu \mathrm{m}$ at $90 \%$ DMF. This can be proved by Fig. 8 in which it is shown that increase in DMF concentration in blends with ethanol resulted in smaller reduction of wear scar compared with gasoline blends. The analysis of results indicates that small amount percentages of DMF to gasoline can improve the lubricity of gasoline more significantly than that of ethanol.

In general, the study of friction coefficient of DMF in blends with ethanol and gasoline illustrate the important role of DMF for enhancement of gasoline lubricity properties. As it is illustrated by the results, DMF has better effect on gasoline lubricity properties

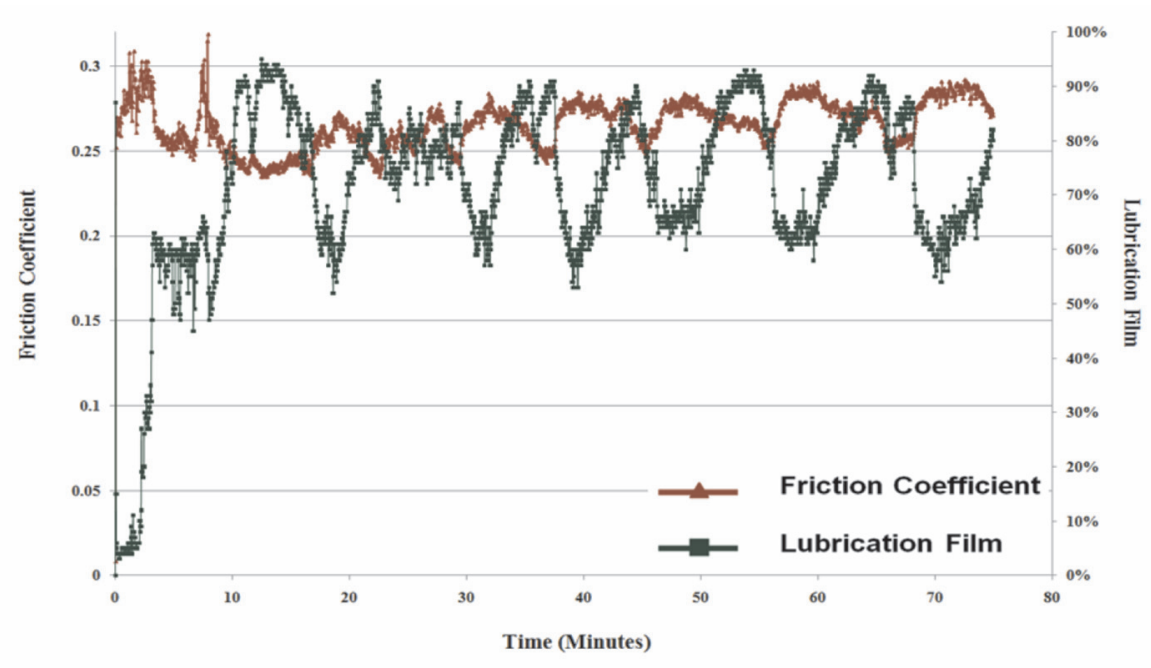

Fig. 9. Inverse relationship of friction coefficient and lubrication film coverage Rys. 9. Odwrotna zależność wspótczynnika tarcia i udziału powierzchniowego filmu
Table 6. Lubricity parameters for non-aged and aged DMF

Tabela 6. Parametry smarności świeżego i sezonowanego paliwa DMF

\begin{tabular}{|c|c|c|c|}
\hline $\begin{array}{c}\text { Fuel/ } \\
\text { paliwo }\end{array}$ & $\begin{array}{c}\text { Average wear scar/ } \\
\text { średnica śladu } \\
\text { zużycia }(\mu \mathrm{m})\end{array}$ & $\begin{array}{c}\text { Average friction } \\
\text { coefficient/średni } \\
\text { wspótczynnik tarcia }\end{array}$ & $\begin{array}{c}\text { Average lubrication film } \\
\text { coverage/średni udziat } \\
\text { filmu }\end{array}$ \\
\hline $\begin{array}{c}\text { Non-aged DMF/świeży } \\
\text { DMF }\end{array}$ & 324 & 0.29 & $49 \%$ \\
\hline $\begin{array}{c}\text { Aged DMF/stary } \\
\text { (sezonowany) DMF }\end{array}$ & 238.5 & 0.271 & $68 \%$ \\
\hline
\end{tabular}

DMF w mieszance na średnice śladu zużycia. Zwiększanie zawartości DMF dla mieszanek $\mathrm{z}$ etanolem daje mniej znaczącą poprawę właściwości smarnych niż dla mieszanek $\mathrm{z}$ benzyną. Nawet niewielki dodatek DMF poprawia bardziej smarność benzyny niż etanolu.

Podsumowując, analiza wpływu zawartości DMF w mieszankach na współczynnik tarcia dowodzi, jak dużą rolę może odegrać DMF jako dodatek do benzyny i etanolu poprawiający smarność. Wyniki badań dowodzą, iż dodatek 2,5-dwumetylofuranu do benzyn skutkuje bardziej znaczącą poprawą właściwości smarnych niż w przypadku mieszania z etanolem. Na rysunku 9 przedstawiono przeciwstawne trendy wiążące udział filmu i współczynnik tarcia dla mieszanki etanolu i DMF (50/50). Wzrost współczynnika tarcia skutkuje obniżeniem udziału filmu - przedstawione wyniki dowodzą, że istnieje odwrotna zależność łącząca udział filmu i współczynnik tarcia. 
in comparison with ethanol. Figure 9 represents inverse relationship of lubrication film coverage and friction coefficient in DMF ethanol blend (50 DMF 50 ETH). As much as friction coefficient is increased, the percentages of lubrication film coverage is decreased and this issue proves that lubrication film and friction coefficient of fuel have inverse relationship.

\section{DMF aging}

2,5-dimethylfuran was stored in dark cupboard at atmosphere condition for seven months to investigate on changes of lubricity properties of fuel after storage. Results on same DMF after seven months showed that the DMF lubricity properties were changed during storage. Results demonstrate

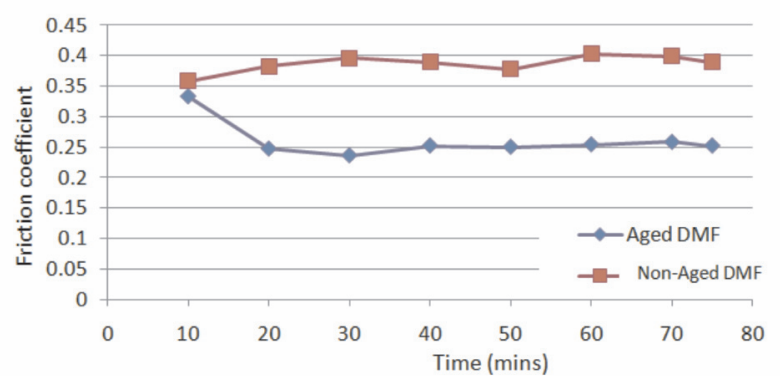

Fig. 10. Comparison of friction coefficient of non-aged DMF and aged DMF

Rys. 10. Porównanie współczynników tarcia świeżego i sezonowanego DMF

lower average wear scar which means better lubricity properties for DMF. Figure 10 illustrates the friction coefficient and lubrication film percentage of the non-aged and aged sample of DMF with respect to time at $35-45 \%$ relative humidity and $25^{\circ} \mathrm{C}$.

The average lubrication film coverage has been varied slightly from $65 \%$ to $68 \%$ and the average friction coefficient is decreased considerably by almost $30 \%$ during seven months. The main reason for these properties changes is high volatility of DMF and also effect of air-trapped in the bottle in which the DMF was stored. Also, wear scar was improved during seven months and aged DMF is $28 \%$ smaller than the non-aged DMF (Fig. 11).

\section{Conclusion}

This study considers effect of DMF (2,5-dimethylfuran) in blends with commercial gasoline and ethanol. Experiment was done in High Frequency Reciprocating Rig (HFRR) with particular test conditions (Tab. 1). Based on the experiments, the following conclusions can be achieved:

1.Pure DMF and ethanol friction coefficient maintained roughly constant values during the experiments, but for gasoline this changed to increasing trend resulting inpoor lubricity of gasoline among other alternatives.

2.DMF enhanced the lubricity of gasoline. By increasing the concentration of DMF lubricity of gasoline improved. This can be mentioned for DMF-ethanol blend as well.

3. Effect of adding DMF to gasoline was more significant in lubricity compared to ethanol.
DMF po siedmiu miesiącach wykazały zmiany smarności. Średnia średnica zużycia jest mniejsza, co wskazuje na lepsze właściwości smarne. Na rysunku 10 przedstawiono zmiany współczynnika tarcia i procentu udziału powierzchniowego filmu smarnego w czasie eksperymentu w warunkach wilgotności względnej 35-45\% i temperatury $25{ }^{\circ} \mathrm{C}$ dla próbek świeżych i sezonowanych. Po upływie 7 miesięcy średni udział powierzchniowy filmu smarnego zmienił się niewiele: z $65 \%$ do $68 \%$, natomiast średni współczynnik tarcia zmniejszył się znacznie, bo prawie o 30\%. Głównym powodem tych zmian właściwości jest prawdopodobnie duża lotność DMF, a także efekt działania powietrza zamkniętego w butli, w której przechowywany był DMF. Nastąpiła również poprawa średnicy zużycia, która w przypadku DMF

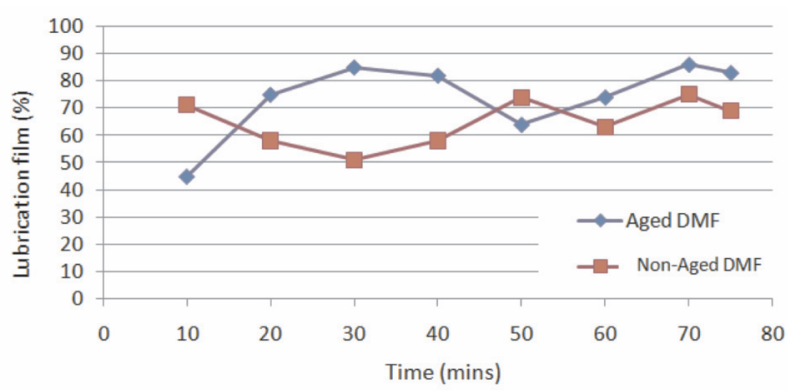

Fig. 11. Comparison of lubrication film coverage of non-aged DMF and aged DMF

Rys. 11. Porównanie udziału powierzchniowego filmu dla świeżego i sezonowanego DMF

sezonowanego przez 7 miesięcy jest o $28 \%$ mniejsza w porównaniu ze średnicą świeżej próbki (rys. 11).

\section{Wnioski}

Niniejsze badania dotyczą efektów DMF (2,5-dwumetylofuranu) w mieszaninach z benzyną (klasy detalicznej) i etanolem. Eksperyment przeprowadzany był w aparacie o ruchu posuwisto-zwrotnym wysokiej częstotliwości (HFRR) w ściśle określonych warunkach testów (tab. 1). W wyniku przeprowadzonych eksperymentów można przedstawić następujące wnioski:

1.Dla czystego DMF i etanolu współczynnik tarcia wykazywał stałe wartości podczas trwania eksperymentu, natomiast dla benzyny wartość współczynnika tarcia wzrastała, skutkiem czego smarność benzyny jest gorsza w porównaniu z jej alternatywnymi paliwami.

2. Dodatek DMF poprawiał smarność benzyny. W miarę wzrostu proporcji DMF następowała dalsza poprawa smarności. To samo można powiedzieć o mieszaninach DMF i etanolu.

3. Efekt poprawy smarności w sytuacji dodawania DMF do benzyny był silniejszy niż przy dodawaniu go do etanolu.

4. Potwierdzono istnienie odwrotnej zależności pomiędzy udziałem powierzchniowym filmu smarnego i współczynnikiem tarcia.

5. Sezonowanie DMF prowadziło do poprawy smarności jego mieszanin z benzyną i etanolem w porównaniu do smarności z ich mieszaninami ze świeżym DMF. 
4. It was confirmed that lubrication film coverage and friction coefficient has inverse relationship.

5.Aging of DMF improved the lubricity of gasoline and ethanol blends compared to those with non-aged fuel.

Overall, these experiments highlight the effective role of DMF and ethanol as an additive or alternative fuel for gasoline in terms of lubricity.

Paper reviewed/Artykut recenzowany
W podsumowaniu - przedstawione tu badania pod względem poprawy smarności podkreślają skuteczną rolę tak DMF, jak i etanolu jako dodatku lub paliwa alternatywnego dla benzyny.

\section{Nomenclature/Oznaczenia}

DMF 2,5-dimethylfuran/2,5-dwumetylofuran

GAS gasoline/benzyna

ETH ethanol/etanol

HFRR High Frequency Reciprocating Rig/HFRR aparat $z$ ruchem posuwisto-zwrotnym wysokiej częstotliwości

\section{Bibliography/Literatura}

[1] Park J., Yoo Y.H.: Corrosion characteristics of aluminium alloy in bioethanol blended gasoline fuel. Fuel 90(2011) 633-639.

[2] Mousdale D.M.: Bio-ethanol as a fuel: biotechnology, biochemical engineering and sustainable development. Boca Raton: CRC Press; 2008.

[3] Wei D., Spikes H.A.: The lubricity of diesel fuels. Wear. 1986, 111:217-235.

[4] Downstream alternatives Inc. (DAI) Lubricity of Reformulated and oxygenated Gasolines. DAI Informational document \#970301, March 1997.

[5] Binder J.B., Raines R.T.: Simple chemical transformation of lignocellulosic biomass into furans for fuels and chemicals. J Am Chem Soc 2009;131(5): p. 1979-1985.

[6] Roman-Leshkov R., Barrett C.J., Liu Z.Y., Dumesic J.A.: Production of dimethylfuran for liquid fuels from biomassderived carbohydrates. Nature 2007, 447, p. 982-986.

[7] Daniel R., Tian G.: Effect of spark timing and load on a DISI engine fuelled with 2,5-dimethylfuran, Fuel 90 (2011), 449-458.

Farshad Eslami, MEng. - research student in the School of Mechanical Engineering at the University of Birmingham, UK.

Inż. Farshad Eslami - pracownik na Wydziale Mechanicznym Uniwersytetu Birmingham, Wielka Brytania.

e-mail:fxe632@bham.ac.uk

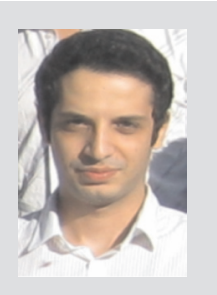

Athanasios Tsolakis, PhD. - senior lecturer in the School of Mechanical Engineering at the University of Birmingham, UK.

Dr Athanasios Tsolakis - starszy wyktadowca na Wydziale Mechanicznym Uniwersytetu Birmingham, Wielka Brytania.

e-mail:A.Tsolakis@bham.ac.uk

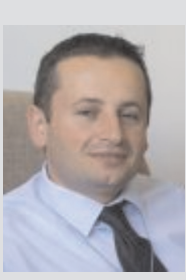

Shahrouz Norouzi - research student in the School of Mechanical Engineering at the University of Birmingham, UK.

Shahrouz Norouzi - student na Wydziale Mechanicznym Uniwersytetu Birmingham, Wielka Brytania.

e-mail:sxn633@bham.ac.uk
[8] Heywood J.B.: Internal Combustion Engine Fundamentals. McGraw-Hill: New York, 1988. ISBN: 0071004998.

[9] Ferguson C.R.: Internal Combustion Engines: Applied Thermosciences. Wiley: New York, 1986 ISBN 13: 9780471356172.

[10] Ping W.D., Korcek S., Spikes H.: Comparison of the lubricity of Gasoline and Diesel Fuels. SAE Tech. Paper 962010, (1996).

[11] Peter R.N., Childs, Stobart R.: Total Vehicle Technology. Proceedings of the 3rd IMechE Automobile Division Southern Centre Conference ISBN: 186058460 8, p. 38.

[12] Lapuerta M., Garcia-Contreras R.: Lubricity of ethanol-biodiesel-diesel fuel blends. Energy Fuels 2010, 24, p. 1374-1379.

[13] Agudelol J., Benjumea P.: The lubricity of ethanol-gasoline fuel blends. Revista Facultad de Ingenieria Universidad de Antiquia, 2011, ISSN 0120-6230, p. 9-16.

Prof. Miroslaw L. Wyszynski, PhD., MSAE, MSIMP. - Professor in the School of Mechanical Engineering at the University of Birmingham, UK.

Prof. dr hab. inż. Miroslaw L. Wyszynski-profesor na Wydziale Mechanicznym Uniwersytetu Birmingham, Wielka Brytania.

e-mail:M.L.Wyszynski@bham.ac.uk

Prof. Hongming Xu, PhD, DIC, MSAE, CEng, FIMechE, FHEA - Professor in the School of Mechanical Engineering at the University of Birmingham, UK. Prof. Hongming Xu - profesor na Wydziale Mechanicznym Uniwersytetu Birmingham, Wielka Brytania.

e-mail:H.M.Xu@bham.ac.uk

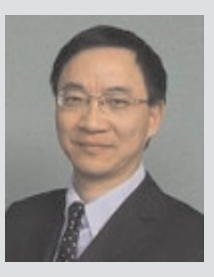

Karl Dearn, PhD. - lecturer in the School of Mechanical Engineering at the University of Birmingham, UK.

Dr Karl Dearn - wykladowca na Wydziale Mechanicznym Uniwersytetu Birmingham, Wielka Brytania.

e-mail:K.D.Dearn@bham.ac.uk 